\title{
Suspension feeding in the polychaete Nereis diversicolor
}

\author{
Hans Ulrik Riisgård \\ Institute of Biology, University of Odense, Campusvej 55, DK-5230 Odense M, Denmark
}

\begin{abstract}
Properties of the pump and filter system were studied in the occasionally suspensionfeeding polychaete Nereis diversicolor. Feeding behaviour was observed on worms in glass tubes immersed in seawater. When algal cells were added to the surrounding water the worm made a funnelshaped net-bag through which water was pumped by means of vigorously undulating movements of the body. Particles suspended in the inhalant water were retained by the net and later swallowed by the worm. The times spent on net-spinning, water-pumping through the complete net bag, and net-eating were: $97 \pm 35,191 \pm 58$, and $16 \pm 4 \mathrm{~s}$, respectively. Stereotyped suspension-feeding behaviour was continuously recorded for $10 \mathrm{~h}$ by means of a computer-aided monitoring system. The volume of water cleared of algal cells (Rhodomonas baltica, diameter $=6.3 \mu \mathrm{m}$ ) per unit time (clearance) was measured in worms of different size. Clearance $\left(C, \mu l \mathrm{~s}^{-1}\right.$ ) as a function of body dry wt ( $\left.W, \mathrm{mg}\right)$ was: $C=3.52+$ $2.46 \mathrm{~W}\left(17^{\circ} \mathrm{C}\right)$. The clearance of $6.3 \mu \mathrm{m}$ algal cells was $86 \%$ of directly measured pumping rate, while the clearance rates of 7.5 and $13.1 \mu \mathrm{m}$ particles were identical with the directly measured pumping rate, thus indicating $100 \%$ retention efficiency of particles $>7.5 \mu \mathrm{m}$. For smaller particles the retention efficiency rapidly decreased to about $30 \%$ for $3 \mu \mathrm{m}$ particles. In order to characterize the Nereis pump the relation between imposed hydrostatic back pressure and pumping rate was measured in a number of worms. In several cases the pumping rate was not influenced by the imposed back pressure up to $3 \mathrm{~mm} \mathrm{H} \mathrm{H}_{2} \mathrm{O}$; but at higher back pressures the pumping rate was reduced simultaneously with a reduction in the undulation frequency. The maximum pressure head was around $8 \mathrm{~mm} \mathrm{H}_{2} \mathrm{O}$. It was found that $N$. diversicolor pumps about $40 \mathrm{l}$ of water per $\mathrm{ml}$ oxygen consumed, and the worm thus fulfills conditions for subsisting exclusively as a suspension feeder. The population pumping rate at the collecting site ( 2400 ind $\mathrm{m}^{-2}$ ) was estimated to $9.8 \mathrm{~m}^{3} \mathrm{~d}^{-1}$ or 10 times the whole water column daily. This indicates that $N$. diversicolor is a hitherto undervalued key organism in the control of phytoplankton production in shallow brackish water areas.
\end{abstract}

\section{INTRODUCTION}

The polychaete Nereis diversicolor is a common and abundant species on shallow soft-bottoms in northwestern Europe. The worm is almost entirely restricted to the littoral zone where it lives in a U-shaped burrow in the sediment. $N$. diversicolor has been described as a carnivore and/or scavenger, but also as a suspensionfeeder and a detritivore, feeding partly by swallowing surface mud around the openings of the burrow (Wells \& Dales 1951, Goerke 1966, Evans 1971). As a predator $N$. diversicolor has been suggested to be an important structuring factor in soft-bottom communities (Rönn et al. 1988). Other studies do not, however, indicate that $N$. diversicolor is an efficient predator (Olafsson \& Persson 1986).

The occurrence of a filter-feeding mechanism in Nereis diversicolor was first described by Harley
(1950), and later confirmed by Goerke (1966). A water current is created by undulating body movements and driven through a mucous net across the burrow. Suspended food particles are retained in the net which is subsequently eaten. This filter-feeding mechanism has been assumed to be part of the worm's normal behaviour, but there is hardly any information about pumping rates, particle retention efficiency, pump characteristics, or the importance of the feeding mechanism in the everyday life of the animal.

The aim of the present work was to study and characterize the pump and filter system of actively suspension-feeding Nereis diversicolor with special reference to the potential ecological significance of the filterfeeding mechanism. Moreover, it was interesting to compare $N$. diversicolor with 2 other species of suspension-feeding polychaetes, Chaetopterus variopedatus (Riisgård 1989) and Sabella penicillus (Riisgård \& 
Ivarsson 1990). All 3 polychaete species have adapted to the same mode of life, but they have coped in different ways with the basic demands of water processing.

\section{MATERIALS AND METHODS}

Ragworms Nereis diversicolor O. F. Müller were collected in May 1990 from mud flats at water depths of about $0.5 \mathrm{~m}$ in the inner part of the brackish (ca $10 \% \mathrm{~S}$ ) Odense Fjord, Denmark. Ten randomly chosen sediment core samples $\left(67 \mathrm{~cm}^{2}, 15 \mathrm{~cm}\right.$ deep) were taken along the coast at Kærby Fed and sieved. Worms that were retained by the sieve (1 $\mathrm{mm}$ mesh size) were brought to the laboratory and individually weighed to determine the population size distribution and density. The worms were then taken to a near constant temperature room $\left(17^{\circ} \mathrm{C}\right)$ at the Biological Institute, University of Odense, and kept in aquaria with $18 \%$ S seawater.

To allow observations of feeding behaviour and to perform direct measurements of pumping rates, the worms were transferred to 12 or $6 \mathrm{~cm}$ long glass tubes of an inner diameter comparable to that of the natural tube. The tubes with worms were kept in aquaria with seawater until experiments could be performed. Worms to be used in clearance experiments using the 'suction method' (see below) were allowed to burrow singly in $200 \mathrm{ml}$ glass beakers placed in aquaria with sediment from the collecting site. The seawater in the aquaria was changed every week, and fresh seawater was used in all experiments. After the first week of residence in the laboratory (during which a number of injured worms died) almost no mortality was noticed during the following 3 mo.

Direct measurements of pumping rates of Nereis diversicolor at different hydrostatic back-pressures (imposed between the inlet and outlet of the glass tube), while simultaneously recording pumping movements, were performed by means of the experimental set-up previously used for the suspension-feeding polychaete Chaetopterus variopedatus (Riisgård 1989). A schematic drawing of the set-up is shown in Fig. 1. An aquarium was divided into 2 chambers $\left(C_{1}\right.$ and $\left.C_{2}\right)$ by a wall with a hole through which the glass tube with the experimental worm was inserted. The water level in the exhalant chamber $\left(C_{2}\right)$ was monitored with a laser beam striking a mirror fixed to a floating pingpong ball which reflected the laser beam onto a scale. When a shunt connecting the 2 chambers was closed the water transport of the worm was counterbalanced by pumping equivalent volumes of water from a reservoir into $C_{1}$ and out of $C_{2}$ into a measuring beaker. This was done by adjusting the pump, thus maintaining the deflection of the laser at a fixed point on the scale equivalent to a known hydrostatic back pressure. The

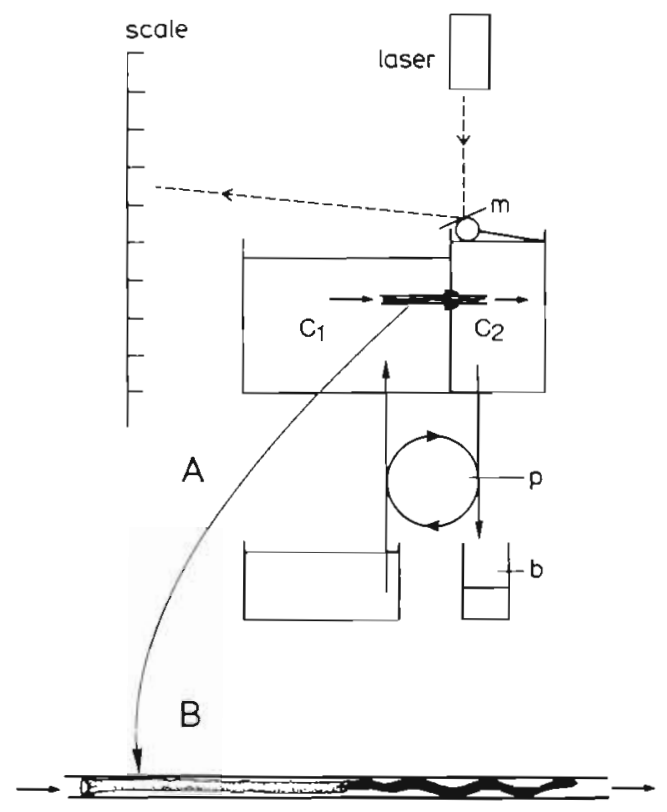

Fig. 1. (A) Experimental set-up used for direct measurement of pumping rates at different hydrostatic pressures imposed between inlet and outlet end of glass tube with Nereis diversicolor inserted in the wall separating the inhalant $\left(\mathrm{C}_{1}\right)$ and exhalant chamber $\left(\mathrm{C}_{2}\right)$. Water level in $\mathrm{C}_{2}$ is monitored with a laser beam striking a mirror $(\mathrm{m})$ fixed on a tethered floating ping-pong ball. Pumping rate of the worm is equal to volume of water collected in the beaker (b) when the laser deflection point is maintained in a constant position on the scale. Drawing partly modified from Riisgård (1989). (B) Lateral view of $N$. diversicolor in a glass tube. Drawing based on photograph (Fig. 3A)

volume of water collected in the beaker per unit time equalled the pumping rate. Fresh seawater and addition of algal cells (ca $10^{4}$ Rhodomonas baltica cells $\mathrm{ml}^{-1}$ ) were adopted as a standard procedure. Transfer of the glass tube with $N$. diversicolor from the holding aquarium to the apparatus for direct measurement of pumping rates usually disturbed the worm for only a short period. After 5 to $15 \mathrm{~min}$ the worm resumed active feeding. All measurements were made on worms pumping water through a mucous net. In several cases the undulation frequency was simultaneously recorded by means of a Panasonic VHS movie camera (NV-M5).

The volume of water cleared of algal cells per unit time (clearance) was measured in Nereis diversicolor within the experimental glass tube by means of the 'clearance method', or by means of the 'suction method' in worms within their natural tubes in sediment. When the 'clearance method' was used clearance $(C)$ was calculated from the rate by which algal cells Rhodomonas baltica were cleared from suspensions by means of the equation: $C=(V / t) \ln \left(C_{0} / C_{t}\right)$, where $V=$ volume of suspension, $t=$ time, $C_{0}$ and $C_{t}=$ algal concentration at time 0 and time $t$. Usually the 
individual specimens were placed in $1 \mathrm{l}$ glass beakers with a known volume of seawater with algae added to concentrations of $4 \times 10^{3}$ to $4 \times 10^{4}$ cells ml-1 $\mathrm{mde}^{-1}$ quate mixing of the suspension was ensured by aeration. Samples $(15 \mathrm{ml})$ for determination of algal cell concentration were taken at 5 or 10 min time intervals. The control was a newly emptied glass tube, flushed with seawater by means of a peristaltic pump that recirculated the water in the glass beaker. No reduction of algal concentration in controls was seen over $120 \mathrm{~min}$.

To determine clearance by means of the 'suction method' (Møhlenberg \& Riisgård 1979) the sedimentcontaining beaker with the worm in its natural tube was placed in a $6 \mathrm{l}$ aquarium with seawater containing added Rhodomonas baltica cells. Samples of inhaled and exhaled water were sucked through glass tubes placed 2 to $4 \mathrm{~mm}$ above the worm's inhalant and exhalant tube openings (see Fig. 2). The flow rate

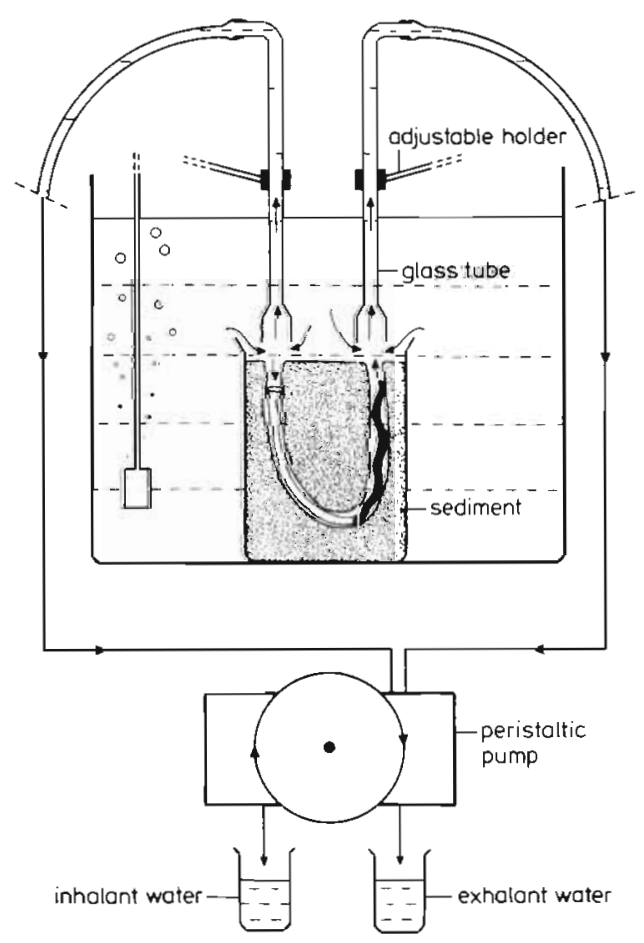

Fig. 2. Experimental set-up for clearance measurements by means of the 'suction method'. The glass tubes, placed about $3 \mathrm{~mm}$ above the sediment surface, collect water from the inhalant and exhalant regions by means of a peristaltic pump

through the glass tubes was varied from 5 to $40 \mathrm{ml}$ $\min ^{-1}$ by means of an adjustable peristaltic pump. The volume of exhaled water cleared of particles per unit time $(Y)$ was calculated as: $Y=F\left(1-C_{e} / C_{1}\right)$, where $F$ is the flow rate through the glass tube, and $C_{\mathrm{i}}$ and $C_{\mathrm{e}}$ the concentrations of algal cells in the water collected simultaneously from the inhalant and exhalant cur- rents, respectively. At high flow rates, when all the exhaled water was sucked through the glass tube, the clearance became independent of flow rate and representative of the true clearance ( $C$ ) of the worm.

In all experiments, the approximately spherical (diameter $6.3 \mu \mathrm{m}$ ) flagellate Rhodomonas baltica was used as food. The algae were cultivated at a constant dilution rate of ca $1 / 4 \mathrm{~d}^{-1}$. The growth medium was enriched $18 \% \mathrm{~S}$ natural seawater. In one series of experiments (retention efficiency) a mixture of algal species - Nanochloris atomus (2 to $3 \mu \mathrm{m})$, Isochrysis galbana (4 to $5 \mu \mathrm{m}$ ), Pyramiformis sp. (5 to $8 \mu \mathrm{m})$, Rhodomonas baltica ( 5 to $7 \mu \mathrm{m}$ ), and latex beads (13.1 $\mu \mathrm{m})$ - was used for simultaneous measurements of clearance of particles of different size.

An Elzone electronic particle counter (Model 80 xy fitted with a $76 \mu \mathrm{m}$ orifice tube) was used to determine particle size distributions and concentrations.

The pumping activity of Nereis diversicolor within the experimental glass tube was monitored during prolonged periods by means of a modified version of the computer-aided physiological monitoring system (CAPMON) developed by Depledge \& Andersen (1990). An infrared phototransducer was attached to the glass tube, and the pumping movements of the worm recorded as strokes $\mathrm{min}^{-1}$ and stored on a computer disc for later analysis.

The oxygen consumption of Nereis diversicolor was measured by placing the glass tube with the worm in a test tube filled with $30 \mathrm{ml}$ oxygen-saturated seawater with added algae and closed with a rubber stopper. The pumping activity of the worm ensured mixing of the water $\left(17^{\circ} \mathrm{C}\right)$ in the respiration tube. The oxygen concentration of the water in the test tube was measured after 220 min with an oxygen electrode (Radiometer) mounted in a constant temperature cell. Water samples for oxygen measurements were taken in the middle of the respiration tube by means of a syringe extended with a $7 \mathrm{~cm}$ plastic tube.

After the experiments, wet weights (after 5 min drainage on filter paper) and dry weights $\left(90^{\circ} \mathrm{C}, 24 \mathrm{~h}\right)$ were determined.

\section{RESULTS}

\section{Suspension-feeding behaviour}

Feeding-behavioural observations were made on Nereis diversicolor in glass tubes immersed in seawater. When a suspension of algal cells (Rhodomonas baltica) was added, the worm moved, within 5 to 15 min, to one end of the glass tube. There it fixed mucous threads to the glass wall, forming the circular opening of a net bag, which was completed (probably by spinning threads secreted by a number of anterior para- 
podial glands) as the worm slowly retreated down the tube, moving the anterior end from side to side in semicircles. While making the funnel-shaped net-bag, and for a period after the bag was completed, the worm pumped water through the net by means of vigorously undulating movements of the body. Particles suspended in the inhalant water were retained by the net and after a certain period of pumping the worm moved forward, swallowing the net bag and its entrapped food particles. The dimensions of the net bag as related to the glass tube diameter and length of the worm, as well as the position of the worm's head within the feeding bag, appear in Fig. 3. Ten feeding cycles in 2 worms (\#1 and \#3) were analysed by video recordings. The times spent on net-spinning, water-pumping through the complete net bag, and net-eating were: $97 \pm 35$, $191 \pm 58$, and $16 \pm 4$ s, respectively. Other recordings of feeding cycles were made with the CAPMON system (see Fig. 4). When algal cells were suspended in the water, the worm started feeding continuously. Periods of vigorous pumping at certain high undulation frequencies were interrupted by net-eating and netspinning periods. Such stereotyped suspension-feeding behaviour was continuously recorded for $10 \mathrm{~h}$ (Fig. $4 E, F)$. Besides individual differences in undulation frequencies and time periods of feeding-cycles, temperature had a noticeable effect on the pumping activity (Fig. 4B). During the pumping phase of the feeding cycle the undulation frequency was observed to decrease slightly. Gradualiy increasing resistance due to an increasing number of captured particles in the mucous net bag may explain this phenomenon (see below).

\section{Clearance, pumping rate and retention efficiency}

Examples of clearance rates measured by the 'clearance method' and the 'suction method' are shown in Figs. $5 \& 6$, respectively. All data obtained on clearance and unrestricted (i.e. zero back pressure) pumping rate measured by means of the direct method are placed together in Table 1. Clearance as a function of body size is shown in Fig. 7. It can be seen that there is good agreement between the 2 clearance methods. This indicates that there are no differences between rates of water processing in worms in natural sediment tubes and worms transferred to experimental glass tubes. On a mean basis the clearance of $6.3 \mathrm{um}$ algal cells is about $86 \%$ of the directly measured pumping rates (Table 1 ). This indicates that 6 to $7 \mu \mathrm{m}$ particles are being retained by the mucous net bag with 80 to $90 \%$ efficiency. This suggestion is supported by the retention efficiency experiment shown in Fig. 8. It is seen that the clearance rates of 7.5 and 13.1 m particles are
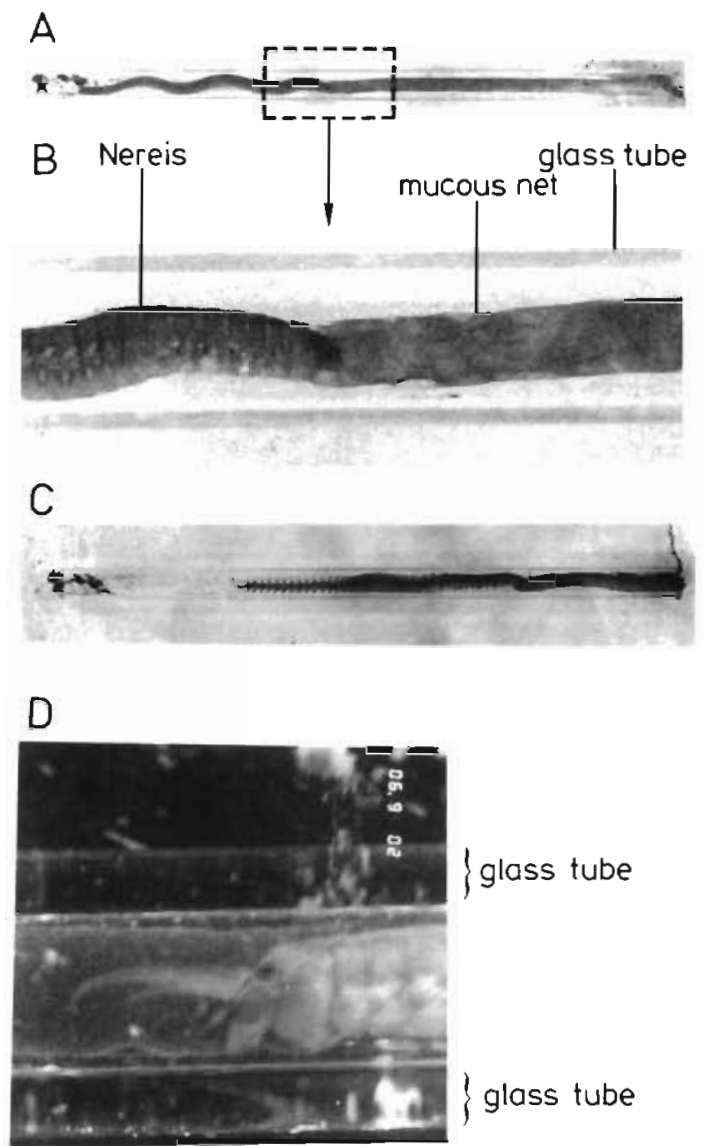

Fig. 3. Nereis diversicolor. (A) Photograph of $N$. diversicolor \#1 lodged in a glass tube (length $=12 \mathrm{~cm}$, inner diameter $=$ $4.4 \mathrm{~mm}$ ). The worm is seen from the side so that the undulating body movements, which produce a water current through the tube, can be seen. When the water passes through the tube it is filtered through a mucous net bag (length $=6.3 \mathrm{~cm}$, diameter $2.6 \mathrm{~mm}$ ) which has been made visible by means of suspended carmine powder added to the inlet with a pipette. The area of the net bag is calculated to be $5.2 \mathrm{~cm}^{2}$, and with a pumping rate of $0.132 \mathrm{~cm}^{3} \mathrm{~s}^{-1}$ (Table 1) the flow velocity through the net is $0.132 / 5.2=0.3 \mathrm{~mm} \mathrm{~s}^{-1}$ (B) Magnification of anterior end of the same worm as shown in (A). (C) Near dorsal-ventral view of worm \#1 while swallowing the mucous net bag 3 min after photograph (A) was taken. (D) Macro photography of anterior end of $N$. diversicolor \#11 in a glass tube (inner diameter $2.3 \mathrm{~mm}$, outer diameter $39 \mathrm{~mm}$ ). The head with forward-stretched peristomial cirri is seen within the mucous bag which has been made visible by means of trapped algal cells. The net bag surrounds the peristomium and seems to be fastened to the body just behind the 'head'

similar and nearly identical with the directly measured pumping rate, thus indicating a $100 \%$ retention efficiency of particles larger than $7.5 \mu \mathrm{m}$. For smaller particles the retention efficiency rapidly decreases to about $30 \%$ for $3 \mu \mathrm{m}$ particles.

The respiration rates measured in 4 Nereis diversicolor lodged in glass tubes are shown in Table 1. The mean respiration rate of the 4 worms was 


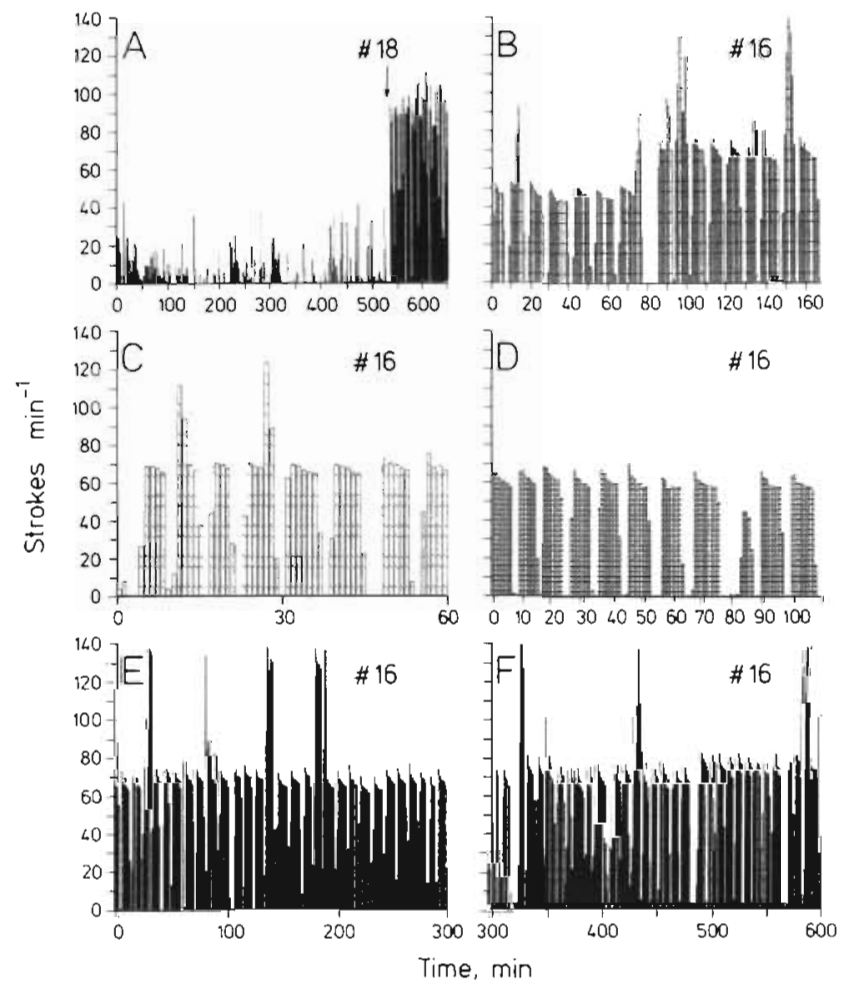

Fig. 4. Nereis diversicolor. Pumping activity in worms recorded by means of an infrared phototransducer fastened to the glass tube. Undulating body movements were monitored as strokes $\mathrm{min}^{-1}$ and plotted as a function of time (note different time scale). (A) $N$. diversicolor \#18 monitored during 650 min. During the first 530 min the worm was unfed. Algal cells were then added (arrow), and the worm started to pump at a high constant rate. (B) Pumping activity in $N$. diversicolor \#16 recorded at $12^{\circ} \mathrm{C}$ during the first 75 min and then, after the temperature was elevated to $19^{\circ} \mathrm{C}$, during an $85 \mathrm{~min}$ period. The algal concentration was ca $2 \times 10^{4}$ cells $\mathrm{ml}^{-1}$ It can be seen that the mean stroke frequency of 45 to 50 strokes $\mathrm{min}^{-1}$ at $12^{\circ} \mathrm{C}$ increased to 65 to 70 strokes $\mathrm{min}^{-1}$ at $19^{\circ} \mathrm{C}$. (C) Examples of feeding cycles in $N$. diversicolor \#16. Pumping periods of 5 to $6 \mathrm{~min}$ were followed by net-eating and netspinning periods during which the stroke frequency was zero (net-eating) or reduced (net-spinning). The algal concentration was $1.2 \times 10^{4}$ cells $\mathrm{ml}^{-1}$ in (C) and $2.5 \times 10^{4}$ in (D). Note the systematically reduced stroke frequency during the pumping periods (probably due to increased resistance in the net bag as algal cells were trapped). (E, F) Pumping activity in $N$. diversicolor \#16 fed $10^{4}$ algal cells $\mathrm{ml}^{-1}$ during $600 \mathrm{~min}$ $\left(15^{\circ} \mathrm{C}\right)$. It can be seen that the pumping activity was high and near constant (65 to 75 strokes $\mathrm{min}^{-1}$ ) during the whole period. The irregular and very high stroke frequencies sometimes seen are not real, but due to double recording of undulating movements when the worm had placed itself inappropriately in relation to the phototransducer

$0.0126 \pm 0.0026 \mathrm{ml} \mathrm{h}^{-1}$. The mean body dry wt was $51.5 \pm 5.0 \mathrm{mg}$, and from the relationship between clearance and body size (Fig. 7), and assuming a retention efficiency of $86 \%$ (Table 1), the mean pumping rate is estimated at $0.54 \mathrm{l} \mathrm{h}^{-1}$. Thus the water proces-

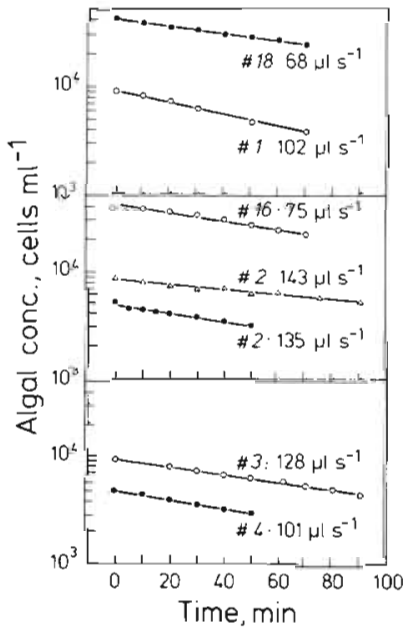

Fig. 5. Nereis diversicolor. Clearance of algal cells (Rhodomonas baltica) in 7 experiments with $N$. diversicolor in glass tubes $\left(17^{\circ} \mathrm{C}\right)$ Regression lines and estimated clearances are shown. Water-pumping undulating body movements (counted by eye and stopwatch at each sampling time) were near constant for the individual worm during the experimental period. Stroke frequencies and volume of seawater used in the different experiments $(V, \mathrm{ml}): \# 1=84$ strokes $\min ^{-1}(V=$ $500 \mathrm{ml}$ ), \#2 $=96$ (open symbols: $V=800 \mathrm{ml}$; closed symbols: $V=1500 \mathrm{ml}), \# 3=75(900), \# 4=91(650), \# 16=74(500)$, \#18=78(500)

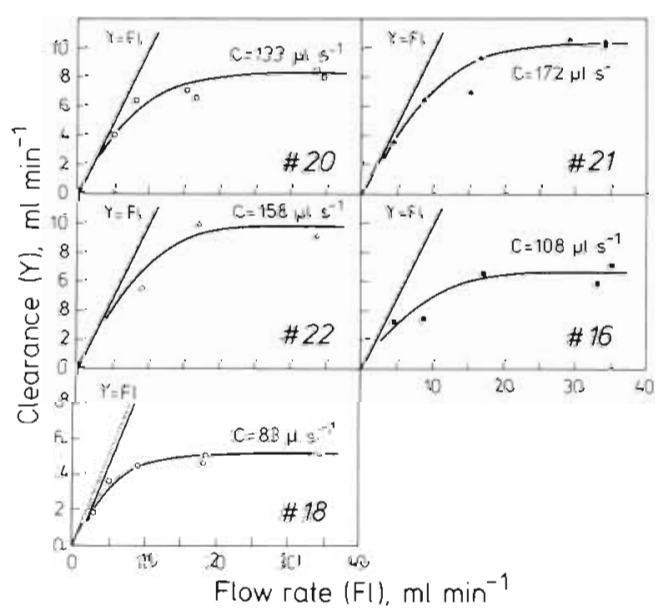

Fig. 6. Nereis diversicolor. Clearance $(Y)$ as a function of suction flow rate in glass tubes collecting water from inhalant and exhalant tube opening $(F)$ in 5 experiments with worms within their natural tubes in sediment (see Fig. 2). Lines for clearance $=$ flow rate $(Y=F)$ are shown; curves are drawn by eye. The plateaus represent the true clearances (C) of the worms

sing capacity is found to be $0.54 / 0.0126=43 \mathrm{l}$ of water filtered per ml of oxygen consumed.

The size distribution and population density of Nereis diversicolor at Kærby Fed, Odense Fjord, appears in Table 2. Based on the estimated individual 
Table 1. Nereis diversicolor. Body weight, pumping rate, clearance of Rhodomonas baltica cells (diameter $=6.3 \mu \mathrm{m}$ ) measured by means of 'clearance method' in worms in glass tubes (CM) or by means of 'suction method' in worms in their natural tubes in sediment (SM), and respiration rate. Mean values und standard deviation from replicate experiments ( $\mathrm{n}$ ) are shown. The mean value of $C / P$ is a measure for the mucous net retention efficiency of $6.3 \mu \mathrm{m}$ particles

\begin{tabular}{|c|c|c|c|c|c|c|}
\hline $\begin{array}{l}\text { Worm } \\
\#\end{array}$ & $\begin{array}{l}\text { Wet weight } \\
\text { (mg) }\end{array}$ & $\begin{array}{l}\text { Dry weight } \\
\text { (mg) }\end{array}$ & $\begin{array}{l}\text { Pumping rate } \\
\left(\mu / \mathrm{s}^{-1}\right)\end{array}$ & $\begin{array}{c}\text { Clearance }(C) \\
\left(\mu 1 s^{-1}\right)\end{array}$ & $\begin{array}{l}C / P \\
(\%)\end{array}$ & $\begin{array}{c}\text { Respiration rate } \\
\quad\left(\mu l \mathrm{O}_{2} \mathrm{~h}^{-1}\right)\end{array}$ \\
\hline 1 & 246 & 25 & 132 & $102(\mathrm{CM})$ & 77 & - \\
\hline 2 & 292 & 42 & - & $139 \pm 6(n=2)(C M)$ & - & - \\
\hline 3 & 294 & 34 & 112 & $128(\mathrm{CM})$ & 114 & - \\
\hline 4 & 265 & 28 & $141 \pm 24(\mathrm{n}=9)$ & $101(\mathrm{CM})$ & 72 & - \\
\hline 5 & 319 & 43 & $168 \pm 13(n=5)$ & $86 \pm 22(n=3)(C M)$ & 51 & - \\
\hline 6 & 358 & 46 & $121 \pm 20(n=4)$ & $116(\mathrm{CM})$ & 96 & - \\
\hline 7 & 72 & 10 & - & 9 (CM) & - & - \\
\hline 8 & 108 & 14 & - & $8(\mathrm{CM})$ & - & - \\
\hline 9 & 57 & 7 & - & $8(\mathrm{CM})$ & - & - \\
\hline 10 & 26 & 4 & - & $13(\mathrm{CM})$ & - & - \\
\hline 11 & 75 & 6 & - & $18(\mathrm{CM})$ & - & - \\
\hline 12 & 101 & 13 & - & $11(\mathrm{CM})$ & - & - \\
\hline 13 & 378 & 47 & $112 \pm 8(n=3)$ & $121(\mathrm{CM})$ & 108 & - \\
\hline 14 & 68 & 7 & - & $16(\mathrm{CM})$ & - & - \\
\hline 15 & 343 & 36 & $157 \pm 3(n=2)$ & $117(\mathrm{CM})$ & 75 & - \\
\hline 16 & 378 & 46 & - & $75(\mathrm{CM}), 108(\mathrm{SM})$ & - & 12.2 \\
\hline 17 & 316 & 31 & $132 \pm 12(n=5)$ & $129(\mathrm{CM})$ & 98 & - \\
\hline 18 & 427 & 50 & - n n & 68 (CM), 83 (SM) & - & 9.4 \\
\hline 19 & 401 & 50 & - & - r n & - & - \\
\hline 20 & 367 & 63 & - & $133(\mathrm{CM})$ & - & - \\
\hline 21 & 437 & 58 & - & $172(\mathrm{CM})$ & - & 15.8 \\
\hline 22 & 416 & 52 & - & \multicolumn{2}{|c|}{ Mean $\pm S D: 86 \pm 20$} & 13.0 \\
\hline
\end{tabular}

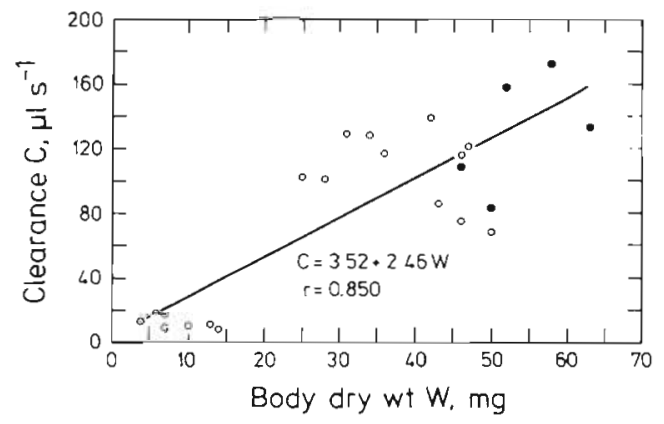

Fig. 7. Nereis diversicolor. Clearance of algal cells $(6.3 \mu \mathrm{m})$ as a function of worm dry weight. Open symbols represent data obtained by means of the 'clearance method' with worms in glass tubes; closed symbols represent values obtained by means of the 'suction method' with worms in natural tubes in sediment. Regression line and its equation are shown. The equation for clearance $\left(C, \mu l s^{-1}\right)$ as a function of body wet weight ( $W, \mathrm{mg})$ was: $C=-13.44+0.40 W(\mathrm{r}=0.945)$

clearance of worms in the different size groups, and assuming a retention efficiency of $86 \%$, the total population pumping rate ( $=$ filtration rate $=$ clearance of $100 \%$ retained particles) was calculated to be $9.8 \mathrm{~m}^{3}$ $\mathrm{d}^{-1}$, which is about 10 times the whole water column at the collecting site.

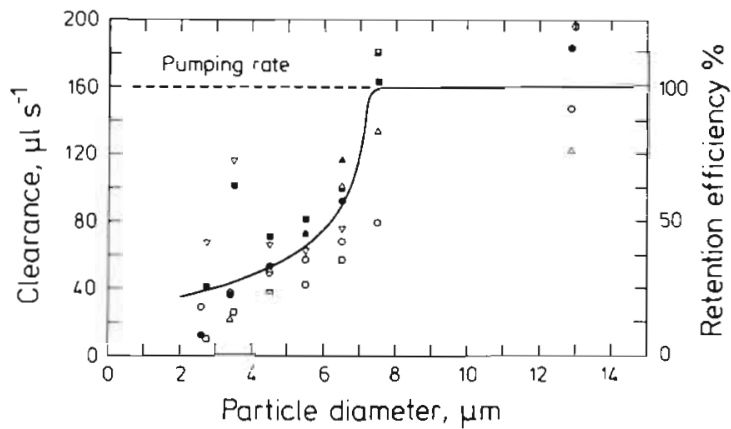

Fig. 8. Nereis diversicolor. Simultaneously measured clearance of different sized particles in replicate experiments with $N$. diversicolor \#15. The curve is drawn by eye, and the directly measured pumping rate on the same worm (Table 1) is indicated. The figure shows that particles above $7.5 \mu \mathrm{m}$ are cleared at a constant rate identical with the pumping rate (i.e. the particles are retained with $100 \%$ efficiency by the mucous net)

\section{Back pressure-pumping rate characteristic}

In order to characterize the Nereis pump the relationship between imposed pressure, $\Delta H_{12}$, and pumping rate, $P$, i.e. the back pressure-pumping rate characteristic, was measured in 6 worms (Fig. 9). From Fig. 9 it 
Table 2. Nereis diversicolor. Size distribution, population density and estimated population pumping rate of worms at Kærby Fed, Odense Fjord, Denmark. The pumping rate of the whole population is calculated as total clearance $(6.3 \mu \mathrm{m}$ algal cells $) \times 100 / 86$ (retention efficiency $=86 \%$ ) $=8.4 \times 1.16=9.8 \mathrm{~m}^{3} \mathrm{~d}^{-1}$

\begin{tabular}{|c|c|c|c|c|}
\hline \multicolumn{2}{|r|}{ Group size } & \multirow{2}{*}{$\begin{array}{c}\text { Density } \\
\text { (ind. } \mathrm{m}^{-2} \text { ) }\end{array}$} & \multicolumn{2}{|c|}{ Clearance } \\
\hline Range & (wet wt, mg) & & $\begin{array}{l}\text { Individual } \\
\left(\mu \mathrm{u} \mathrm{s}^{-1} \text { ind }^{-1}\right)\end{array}$ & $\begin{array}{l}\text { Size group } \\
\left(1 \mathrm{~h}^{-1}\right)\end{array}$ \\
\hline$<50$ & 50 & 1090 & 7 & 26 \\
\hline $50-100$ & 75 & 343 & 17 & 20 \\
\hline $100-150$ & 125 & 269 & 37 & 35 \\
\hline $150-200$ & 175 & 134 & 57 & 27 \\
\hline $200-250$ & 225 & 149 & 77 & 41 \\
\hline $250-300$ & 275 & 164 & 97 & 57 \\
\hline $300-350$ & 325 & 90 & 117 & 38 \\
\hline $350-400$ & 375 & 119 & 137 & 59 \\
\hline $400-450$ & 425 & 45 & 157 & 25 \\
\hline $450-500$ & 475 & 15 & 177 & 10 \\
\hline \multirow[t]{2}{*}{$500-550$} & 525 & 15 & 197 & 11 \\
\hline & & Total $=2433$ & & $=349=8.4 \mathrm{~m}^{3} \mathrm{~d}^{-1}$ \\
\hline
\end{tabular}

is seen that the pumping rate at zero back pressure varies to some extent depending on the undulation frequency. The back pressure-pumping rate measurements were not straightforward to perform because the worms responded to the imposed back pressure by reversing themselves in the glass tube, thus changing the direction of water flow. Therefore, the maximum back pressure at zero pumping rate was not determined, but to judge from the shape of the curves in Fig. 9 the maximum pressure head may be around $8 \mathrm{~mm}$ $\mathrm{H}_{2} \mathrm{O}$. In several cases it was found that the pumping rate not was influenced by the imposed back pressures

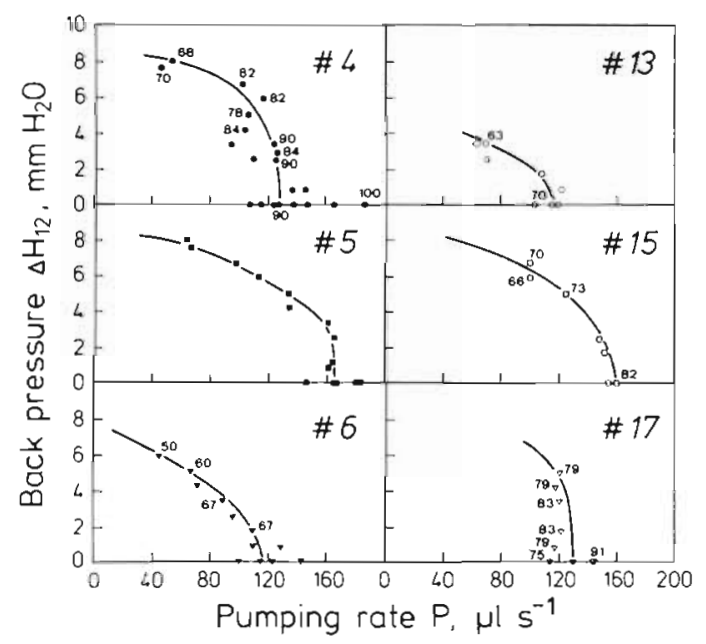

Fig. 9. Nereis diversicolor. Back pressure-pumping rate characteristic in 6 worms $(\# 4,5,6,13,15$ and 17). Frequency of water-pumping undulating body movements (strokes $\min ^{-1}$, recorded simultaneously with direct measurement, is indicated. Lines fitted by eye up to at least $3 \mathrm{~mm} \mathrm{H}_{2} \mathrm{O}$; but at higher back pressures the pumping rate was reduced simultaneously with a reduction in the undulation frequency.

\section{DISCUSSION}

The present work has shown that Nereis diversicolor behaves as a typical marine suspension feeder when food particles are present in the surrounding water. The worm pumps water at a high constant rate (Figs. 4 \& 7) through a mucous bag (Fig. 3) which retains suspended particles $>7.5 \mu \mathrm{m}$ with $100 \%$ efficiency (Fig. 8). To obtain enough food to cover the minimal energy requirements, as assessed from rates of oxygen consumed (Jørgensen 1975), marine suspension feeders need to filter more than $10 \mathrm{l}$ of water per $\mathrm{ml}$ of oxygen consumed. In the present work it was found that $N$. diversicolor pumps about $40 \mathrm{l}$ of water per $\mathrm{ml}$ oxygen consumed. The worm thus fulfills the conditions for subsisting exclusively as a suspension feeder. The estimated population pumping rate (Table 2), which may be 10 times the whole water column daily, indicates that $N$. diversicolor is a hitherto undervalued key organism in the control of phytoplankton production in shallow brackish water areas, where population densities of $N$. diversicolor are comparable with the 2400 ind $\mathrm{m}^{-2}$ reported in the present work; cf. 3700 'large' $N$. diversicolor $\mathrm{m}^{-2}$ in the Vellerup Vig, Denmark (Rasmussen 1973); 2000 to $20000 \mathrm{~m}^{-2}$ $(0.5 \mathrm{~mm}$ sieve) on the southwestern coast of Sweden (Olafsson \& Persson 1986). It remains unknown to what extent $N$. diversicolor utilizes its potential to subsist on suspended food particles in nature. It seems well documented that the worm can act as a predator/ 
scavenger, confirmed by e.g. fragments of Corophium found in the guts of wild worms (Rönn et al, 1988). During the present study starved $N$. diversicolor was seen to creep out of its burrow and grab, with its powerful jaws, pieces of mussel meat placed on the sediment surface 4 to $8 \mathrm{~cm}$ from the tube opening. Within a few minutes the meat was dragged down into the tube to be eaten by the worm. In conclusion $N$. diversicolor may be considered a suspension feeder, when a sufficient number of algal cells are present in the water, but the worm may occasionally act as a predator/scavenger. This statement emphasizes the need for more knowledge about the interplay between the suspension-feeding activity of $N$. diversicolor and actual algal concentrations in shallow soft-bottom areas, and the relative importance of alternative ratritional possibilities.

The Nereis diversicolor pump and filter system may be compared to that of 2 other suspension-feeding polychaetes, Chaetopterus variopedatus (Riisgård 1989) and Sabella penicillus (Riisgård \& Ivarsson 1990). All 3 polychaete species have adapted to the same mode of life, i.e. suspension feeding, but have developed very different pump and filter systems to comply with the basic demands of filter-feeding: to process large volumes of water for a modest yield of food. Water-processing capacities of 25 to $50 \mathrm{l}$ of water filtered per $\mathrm{ml}$ of oxygen consumed in C. variopedatus, and about $350 \mathrm{l}$ per $\mathrm{ml}$ oxygen in $S$. penicillus, may be compared to 43 I per ml oxygen consumed by Nereis diversicolor. C. variopedatus retains particles down to about $1.5 \mu \mathrm{m}$ with $100 \%$ efficiency with its mucous net, while the retention efficiency in $N$. diversicolor rapidly declines below $7 \mu \mathrm{m}$. In the ciliary feeding $S$. penicillus the retention efficiency declines below $3 \mu \mathrm{m}$. In $S$. penicillus it was found that the clearance is high and constant at algal (Dunaliella marina, ca $6 \mu \mathrm{m}$ ) concentrations below about $4 \times 10^{3}$ cells $\mathrm{ml}^{-1}$, but at higher algal concentrations the filtration rate is reduced, probably due to overloading of the gut. In the present work no reduction in filtration rate was noticed during $10 \mathrm{~h}$ at $10^{4}$ algal cells $\mathrm{ml}^{-1}$ (Fig. $4 \mathrm{E}, \mathrm{F}$ ) or during ca $3 \mathrm{~h}$ at $2 \times$ $10^{4}$ cells $\mathrm{ml}^{-1}$ (Fig. 4B). Such differences may reflect evolutionary adaptations of the pump, filter and digestive system to biotopes differing in size and amounts of suspended food particles ('optimized pumps'). It is unlikely that the observed differences are due to limitations imposed by energetic expenses of water processing, because the power output $(P)$ as related to metabolic rate $(R)$ is: $P / R=0.4 \%$ in $S$. penicillus and $4 \%$ in C. variopedatus (Riisgård \& Ivarsson 1990). The power output from the $N$. diversicolor pump, calculated as pumping pressure times pumping rate, cannot be estimated without knowledge of the system resistance. The pressure drop across the mucous net is suggested to be the main component of the system resistance, but without knowledge of the mucous net dimensions the pressure drop cannot be calculated. A qualified assessment of the resistance may however be made. The flow velocity through the mucous net of $N$. diversicolor was found to be $0.3 \mathrm{~mm} \mathrm{~s}^{-1}$ (see text to Fig. 3) which may be compared to $0.15 \mathrm{~mm} \mathrm{~s}^{-1}$ in C. variopedatus. Because the retention efficiency is higher in C. variopedatus (pore width about $1.5 \mu \mathrm{m}$ ) than in $N$. diversicolor (pore width about $7 \mu \mathrm{m}$ ) the pressure drop across the mucous nets of the 2 worms is likely to be similar (i.e. about $0.7 \mathrm{~mm} \mathrm{H}_{2} \mathrm{O}$ ). The power output from the 2 types of muscular piston pumps may thus be much the same. The oxygen consumption of a $50 \mathrm{mg}$ dry body weight C. variopedatus was found to be $19 \mu \mathrm{h}^{-1}$ by Riisgard (1989), which may be compared to about $13 \mu \mathrm{h}^{-1}$ for a $N$. diversicolor of similar size (Table 1). Therefore, the metabolic power used for water pumping in the 2 polychaete species seems to be similar. The same conclusion may be advanced for the back pressure-pumping rate characteristic (and thus for the pump characteristic) of the 2 species. The filter and pump system of $N$. diversicolor is strikingly similar to that of the definitely suspension-feeding $C$. variopedatus. The operating pressure in the ciliary crown-filament pump $S$. penicillus is relatively low, ca $0.02 \mathrm{~mm} \mathrm{H}_{2} \mathrm{O}$, compared to the muscular piston pump in C. variopedatus (and $N$. diversicolor), ca $0.7 \mathrm{~mm} \mathrm{H}_{2} \mathrm{O}$. The metabolic rate of a $50 \mathrm{mg}$ dry wt $S$. penicillus is $18 \mu \mathrm{l} \mathrm{O} \mathrm{h}^{-1}$, compared to 19 and $13 \mu \mathrm{O}_{2} \mathrm{~h}^{-1}$ in C. variopedatus and $N$. diversicolor, respectively. This indicates that the energetic costs of the different filter and pump systems developed in the 3 polychaete species are quite similar and not a limiting factor (because the power output in all cases only makes up a minor fraction of the total metabolic rate of the worm)

The present work recognises the importance of distinguishing between resting/unfed and actively suspension-feeding worms (Fig. 4A), Obviously, the ventilation patterns and rates measured by Wells \& Dales (1951), Evans et al. (1974), Scott et al. (1976), FosterSmith (1978), and Kristensen (1981, 1983a, b) in Nereis diversicolor and other possible suspension-feeding polychaetes do not represent suspension-feeding worms

Acknowledgements. Thanks are due to Prof. C. Barker Jørgensen and Dr V Forbes for cntically reading the manuscript.

\section{LITERATURE CITED}

Depledge, M. H., Anclersen, B. B. (1990). A computer-anded physiological monitoring system for continuous, long-term recording of cardiac activity in selected invertebrates. Comp. Biochem. Physiol. 96: 473-477 
Evans, S. M. (1971). Behavior in polychaetes. Q. Rev. Biol. 46 $379-405$

Evans, S. M., Cram, A., Rogers, F. (1974). Spontaneous activity and responses to stimulation in the polychaete Nereis diversicolor (O. F. Müller). Mar Behav. Physiol. 3: 35-58

Foster-Smith, R. L. (1978). An analysis of water flow in tubeliving animals. J. exp. mar. Biol. Ecol. 34: 73-95

Goerke, H. (1966). Nahrungsfiltration von Nereis diversicolor O. F. Müller (Nereidae, Polychaeta). Veröff. Inst. Meeresforsch. Bremerh. 10: 49-58

Harley, M. B. (1950). Occurrence of a filter-feeding mechanism in the polychaete Nereis diversicolor. Nature, Lond 165: $734-735$

Jorgensen, C. B. (1975). Comparative physiology of suspension feeding. Ann. Rev. Physiol. 30: $391-454$

Kristensen, E. (1981). Direct measurement of ventilation and oxygen uptake in three species of tubicolous polychaetes (Nereis spp.). J. comp. Physiol. 145: 45-50

Kristensen, E. (1983a). Ventilation and oxygen uptake by three species of Nereis (Annelida: Polychaeta). I. Effects of hypoxia. Mar. Ecol. Prog. Ser 12: 289-297

Kristensen, E. (1983b). Ventilation and oxygen uptake by three species of Nereis (Annelida: Polychaeta). II. Effects of temperature and salinity changes. Mar Ecol. Prog. Ser. 12: 299-306

Møhlenberg, F., Riisgård, H. U. (1979). Filtration rate, using a new indirect technique, in thirteen species of suspension feeding bivalves. Mar. Biol. 54: 143-147

This article was submitted to the editor
Olafsson, E. B., Persson, L.-E. (1986). The interaction between Nereis diversicolor O. F. Muller and Corophium volutator Pallas as a structuring force in a shallow brackish sediment. J. exp. mar Biol. Ecol. 103: 103-117

Rasmussen, E. (1973). Systematics and ecology of the Isefjord marine fauna (Denmark). Ophelia 11: 1-495

Riisgard, H. U. (1989). Properties and energy cost of the muscular piston pump in the suspension feeding polychaete Chaetopterus variopedatus. Mar Ecol. Prog. Ser. 56: 157-168

Riisgắrd, H. U., Ivarsson, N. M. (1990). The crown-filament pump of the suspension-feeding polychaete Sabella penicillus: filtration, effects of temperature, and energy cost. Mar. Ecol. Prog. Ser. 62: 249--257

Rönn, C., Bronsdorff, E., Nelson, W G. (1988). Predation as a mechanism of interference within infauna in shallow brackish water soft bottoms; experiments with an infauna predator, Nereis diversicolor O. F. Müller. J. exp. mar. Biol Ecol. 116: 143-157

Scott, D. M., Mazurkiewicz, M., Leeman, P. (1976). The longterm monitoring of ventilation rhythms of the polychaetous annelid Nereis virens Sars. Comp. Biochem. Physiol. 53 $65-68$

Wells, G. P., Dales, R. P. (1951). Spontaneous activity patterns in animal behaviour: the irrigation of the burrow in the polychaetes Chaetopterus variopedatus Renier and Nereis diversicolor O. F. Muller J. mar biol. Ass. U. K. 29: $661-680$

Manuscript first received: September 21, 1990

Revised version accepted: November 14, 1990 